\title{
SHAPING THE ANALYTIC MATRIX FOR DEVELOPMENT PLANNING IN THE TERRITORIES: THE KAMCHATKA, RUSSIA CASE
}

\begin{abstract}
Barabashev Alexey G.
Doctor of Philosophy, Professor of HSE, Head of the Department of State and Municipal Service. Address: National Research University Higher School of Economics.

20 Myasnitskaya Str., 101000 Moscow, Russian Federation. E-mail: abarabashev@hse.ru Research Associate: Centre for Public Management and Governance, Faculty of Management, University of Johannesburg, PO Box 524, Auckland Park, 2006 South Africa.
\end{abstract}

\section{Semenov Sergey A.}

Ph.D., Associate Professor of PFUR, Head of the Department of State and Municipal Administration. Address: University of People's Friendship. 10/2 M.Maclay Str., 117198 Moscow, Russian Federation. E-mail: sas29120@gmail.com

\begin{abstract}
The planning of the territories' development as well as the analysis of their capacity for an effective cluster policy have recently been blocked by the absence of appropriate instruments to support strategic decisions in the area of public management . At the same time, many such instruments exist on the level of business sector planning. Strategic management provides various tools allowing the development of the best plan for a company's development, and the means to evaluate the plan's implementation. Modification of the Analytic Matrix of McKinsey, as will be shown, could be a possible variant for the evaluation of the territories' development. The selection of test-region for the implementation of proposed technology was based on some of the principles described. According to these principles, the test region for a McKinsey-type matrix of territorial strategy elaboration was selected, i.e. Kamchatka region. For Kamchatka region, the best criteria for development are specified, namely the fishing (and fish products) industry, plus the shipbuilding (and repair) industry.
\end{abstract}

Keywords: McKinsey Matrix; territorial development; strategy of regional development; ex-ante evaluation for regional governance.

\section{Introduction: a brief history of the elaboration of the territories' development instruments}

Territory development, at least in Russia, is currently operated on the basis of an instrument called the "Strategy of Territories Development". The history of this instrument's elaboration in Russia is traced back to 1992. It was originally 
based on a series of regional Decrees by the President of Russia, and on the Resolutions (Postanovleniya) of the Russian Government's initial legal measures for stabilizing the economic and social situation in the Russian regions ${ }^{1}$. Later, in 1995, the Federal Law "About State Forecasting and Programs of Social-economic Development of the Russian Federation" 2 introduced the legal foundations for the mid-term planning of territorial development. However, the Law has some gaps in the regulation of processes and methods of planning, and in the evaluation of the effectiveness of territorial development under the conditions of a transitional economy.

In 2002, the next step in regional planning was carried out by the Russian Ministry of Economic Development and Trade: a Ministerial Order regarding a general pattern (Template) for the elaboration of regional programs for territorial development was issued ${ }^{3}$. Implementation of regional planning in practice began with this Order (Barabashev \& Semenov, 2014). The Order also regulates the mechanisms for the coordination of regional programs with Federal governmental bodies. It became especially significant later on because of the regional programs' coordination with the Program of the Social-economic Development of Russia in the Mid-term Period 2006-2008 which was approved in 20064.

In 2008, the Mid-term Russian Program of Social-economic Development was replaced by the Concept of the Long-range Social-economic Development of Russia that was issued by Russian Government ${ }^{5}$. The Concept introduced the idea of a territorial industrial cluster Network with high competitive economic potential. Later, in 2008, the Methodical Recommendations on the Implementation of Cluster Policy in Regions of Russia ${ }^{6}$ was introduced by the Ministry of Economic Development and Trade. As the result, we can say that the epoch of massive territorial development programming and of broad preparation of regional strategies of development on levels of Russian Subjects and on a municipality level starts from 2009-2010.

\footnotetext{
Ukaz Prezidenta RF ot 27.02.1992 N 197 «O neotlozhnykh merakh po stabilizatsii ekonomiki, razvitiyu sotsialnoy sfery i okhrane okruzhayushchey sredy Respubliki Bashkortostan».http://bestpravo.ru/rossijskoje/ ej-praktika/a9r.htm;

Postanovleniye Pravitelstva RF ot 28.04.1994 N 412 «Ob osnovnykh merakh gosudarstvennoy podderzhki ekonomiki Respubliki Buryatiya v 1994-1995 godakh». http://www.bestpravo.ru/rossijskoje/rf-praktika/ i7p.htm

2 Federalny zakon N 115-FZ ot 20 iyulya 1995 g. «O gosudarstvennom prognozirovanii i programmakh sotsialno-ekonomicheskogo razvitiya Rossyskoy Federatsii». http://bestpravo.ru/rossijskoje/er-instrukcii/ j7g.htm

3 Prikaz Minekonomrazvitiya Rossii N 170 ot 17 iyunya 2002 g. «O sovershenstvovanii razrabotki, utverzhdeniya i realizatsii programm ekonomicheskogo i sotsialnogo razvitiya subyektov Rossyskoy Federatsii». http://russia.bestpravo.ru/fed2002/data05/tex19746.htm

4 Rasporyazheniye Pravitelstva RF ot 19.01.2006 N 38-r «O programme sotsialno-ekonomicheskogo razvitiya Rossyskoy Federatsii na srednesrochnuyu perspektivu (2006 2008 gody)». http://russia.bestpravo.ru/ fed2006/data07/tex23712.htm

5 Rasporyazheniye Pravitelstva RF ot 17.11.2008 N 1662-r «O Kontseptsii dolgosrochnogo sotsialnoekonomicheskogo razvitiya Rossyskoy Federatsii na period do 2020 goda». http://www.bestpravo.ru/ federalnoje/hj-zakony/mlp.htm

6 Metodicheskiye rekomendatsii po realizatsii klasternoy politiki v subyektakh Rossyskoy Federatsii (ot 26.12.2008 g. № 20636-AK/D19). http://economy.gov.ru/minec/activity/sections/innovations/development/ doc1248781537747
} 
The existing practice of Russian strategies in regional and municipal development has, on one hand, a lot in common with practices in the EU. The process of European "clusterization" from the late 1990s, triggered by active regional and industrial politics (Enright, 2000; Glasmeier, 2000) shows the same rapid growth and positive results during the initial phase (OECD, 2001; Porter, 2005; Regional clusters in Europe, 2002; Diversification of Kazakhstan's Economy, 2004; Sölvell, Lindqvist \& Ketels, 2003; Andersson, Hansson, Serger \& Sörvik, 2004). For several countries, the development of economic industrial clusters became a form of industrial policy (Johnson, Scholes \& Whittington, 2007). Logic, based on the "selection of winners", shows the positive effects of concentrating on best practices and on the stimulus for potentially productive regional economic activity. At the same time, the negative moments, or weak points of territorial cluster/strategy planning, consist of underdeveloped instruments for the analysis of strategy evaluation. A SWOT analysis mostly realized, as a description of external possibilities and internal problems (risks), that it is not enough for final recommendations and argued policy decisions, as was quite clearly visible in Strategy of Vologda Region of Russia (Strategiya sotsialno-ekonomicheskogo razvitiya Vologodskoy oblasti, 2013). Priorities and compromises for regional development are not explained in a clear way and the composition of different elements of strategy is not calculated. A simple extension of the number of indicators for effective evaluation of strategy elaboration and implementation should be replaced by a systemic approach, and the indicators must be attributed to groups that could allow evaluation of the strategy of regional development, both in its components, and in its implementation mechanisms, clearly.

\section{Basic requirements for systematic territorial strategy evaluation}

The basic requirements for territorial strategy evaluation consist of: 1) there should be expert consensus in understanding how to select, for evaluation, the significant, factual data representing different aspects of territorial (municipality, city, region) development. To select data, to distribute it into groups or blocs, and to find the principles of group relations is both a theoretic and methodical problem; 2) to specify the most effective goal-oriented measures on how to impact the system and its elements; 3 ) to take into account the specifics of the system itself, including the real factors, and to divide the factors according to the principle, whether the factor blocks or helps strategy implementation, to connect the factors with the collected data; 4 ) to complete the plan of territorial development/ strategy implementation based on the selection of effective measures. Broadly speaking, these are the requirements of the systemic and implementation-oriented evaluation of the strategy of territorial development.

The theories that are relevant to the above mentioned requirements are located at the intersection of strategic management and programs and policy evaluation theory. Strategic management is mostly oriented on the instruments of businessstructure support, the elements of resource evaluation, possible volume of investments, the markets of goods distribution, of sustainability of business, etc. Every company is oriented on measured indicators because the company should have 
some clear plan of development and should know how to evaluate, and whether a plan is successfully implemented or has failed. Strategic changes should be measured, and the principal significance of such an approach is noted in various research (Johnson, Scholes \& Whittington, 2007, p. 683-691). The requirement to measure strategic changes exists also in the field of state governance evaluation (Mulgan, 2011, p. 389-411).

Program and policy evaluation theory, on the other hand, has long been experienced in the elaboration and implementation of instruments for ex-ante evaluation, especially in risk-evaluation. In Russia, this foresight developed more than other approaches, and it is concentrated pre-evaluation in sectorial programs and politics, such as education and science policies and programs, as represented in the leading Russian Journal "Foresight-Russia" (available at: http://foresight-journal.hse.ru/en/). If the risks are strong, the programs and policies are not allowed to be executed.

\section{Research Task and Hypothesis}

How do we combine the instruments and approaches elaborated in the field of strategic management (business-structure planning), and in the field of program and policy evaluation (risk evaluation), for better evaluation of the strategies of territorial development?

Our task: to prepare the territory plan of development and provide multifactor analysis of the positioning of the elements of the territorial system in regards to territory strategy and plan of development on the basis of a logical scheme which is similar to the logic proposed originally by the McKinsey company for analysis of conglomerated socio-economic structures. This is the so-called Analytic Matrix of McKinsey (available at: http://www.mckinsey. com/insights/strategy/enduring_ideas_the_ge_and_mckinsey_nine-box_matrix; http://www.12manage.com/methods_ge_mckinsey.html). Suffice to say, we would like to combine the instrument for the preparation of a measured plan of company development with the instrument of evaluation created for programs and policy preparation. For such a purpose, we will change the basic parameters of the McKinsey model and include into the Analytic Matrix selected (according to the goals of development) indicators of territorial development instead of business indicators.

The hypothesis of our research is: modernization of the McKinsey Matrix (the quasi-McKinsey Matrix) can be used as a possible tool for territory development evaluation. We will show that the results of multi-factor evaluations by the quasi-Matrix can be combined into the table that can visibly demonstrate the elements which should be first in line for territory business support. Here, the aggregate index of "market attractiveness of territory" can include the complex of development goals of a territory, and the aggregate index of "competitiveness (strength) of socio-economic structure" will be transformed into the aggregate index of the strength of all economic structures located in the territory. Such an approach could help to produce the next generation of territorial strategies of development (Nikolaev \& Tochilkina, 2006). 


\section{Matrix description}

To select the required indicators of territorial development, we should take into account the complex of priorities. Estimated financial expenses and results, social goals and limitations, qualified personnel limitations and demographic conditions, peculiarities of infrastructure support for changes, local legislative acts' influence on development conditions, accessible material resources, multiplicative effects, possibility of creating an effective system of implementation and control, different risks, etc. How do we select the system of qualitative and quantitative indicators for evaluation on the basis of such heterogeneous priorities, and how do we choose the most attractive for investment and for the priorities of the citizens?

The guided principles to choose the priorities and indicators could be based on the following positions:

- Levels of significance of priorities and indicators should be the consensus of experts;

- The Elements of territorial development should be extracted in accordance with priorities;

- Elements of territorial development should be measured;

- Data should be collected for a period of at least a couple of years;

- Indicators for measuring the progress in priority achievements should be supplied by practically realized mechanisms or procedures of measurement. These principles provide some space for multi-factor consensus in analytic descriptions of the conditions of the system. Namely, it can be described as a complex matrix that reflects the quality of factors in one dimension, and the correlation with actors positions/interest in the goals of system development in another dimension.

Such logic of analytics is well-known and reflected in different analytic models and matrixes in the business sector. At the beginning of the 1970s consultants from McKinsey \& Co jointly with General Electric elaborated a complex instrument for the strategic planning of development portfolios (Aaker, 1995; Hax \& Majluf, 1990). The reason for the creation of such a matrix was to elaborate a reliable method for the evaluation of companies development plans, with the possibility to take into account the possibilities and prospects of development of its different (in functional destinations and market positions) sub-structures. The quality of an element and its correspondence to the system (company) as a whole is a crucial basis for its support or termination. A decision about selection results is the identification of a winner, based on the result of a complex, multi-factor evaluation of the correspondence of elements to the general goals of the company.

The aggregated indicator of matrix "market attractiveness" in our case could include the complex of general elements of the goal system for territorial development, and the aggregated indicator of "competitiveness" could include the complex of relevant indicators for different economic agents of territory activity. The data for cluster policy is actually incorporated into the matrix.

Transformation of a McKinsey-type Matrix to the new Matrix can be described graphically as the transition from Table 1 to Table 2 . 


\section{McKinsey-type Matrix}

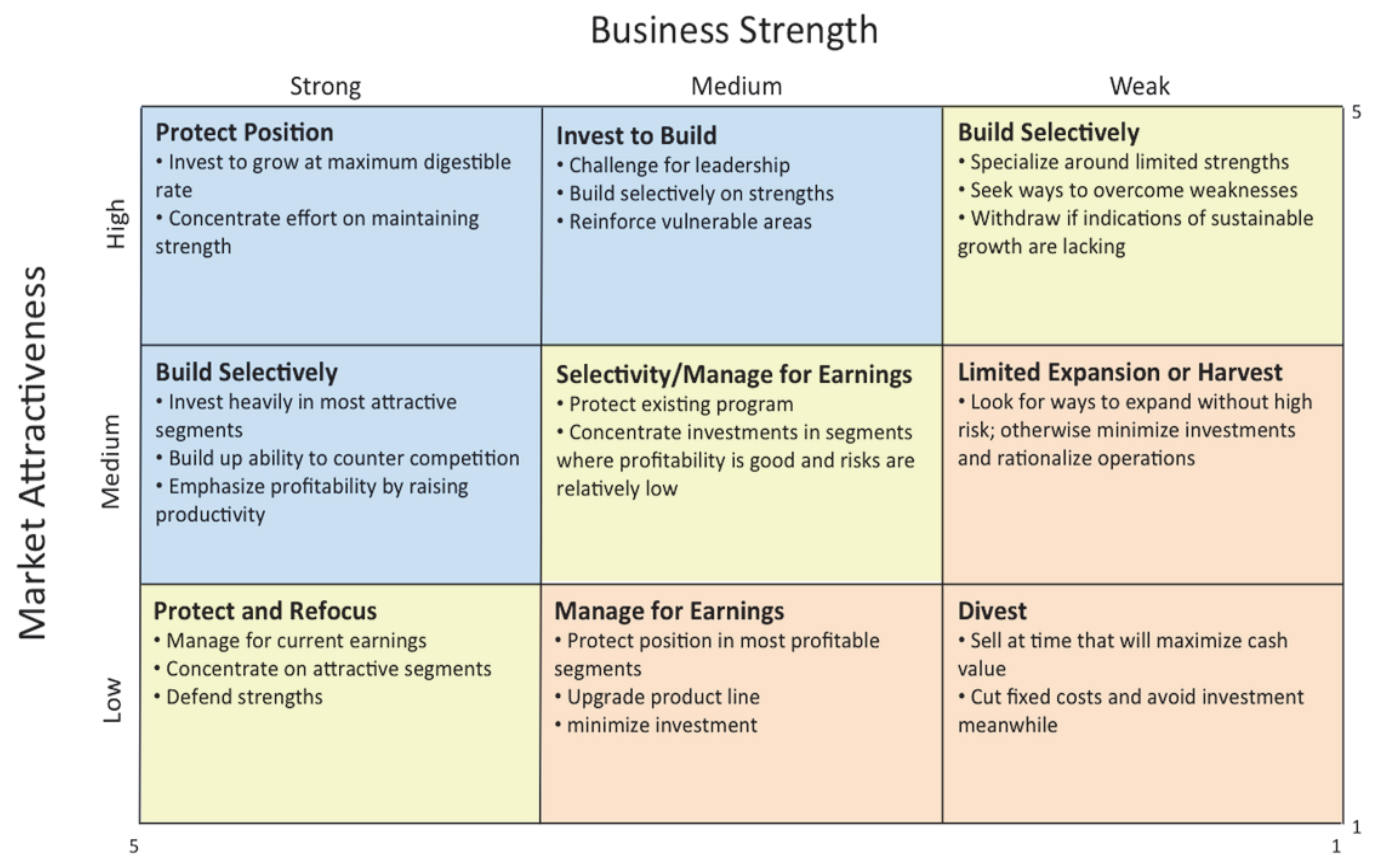

Table 2

\section{Strength of Territorial Business for Strategy of Territorial Development Evaluation}

\begin{tabular}{|c|c|c|c|c|}
\hline \multirow{4}{*}{ 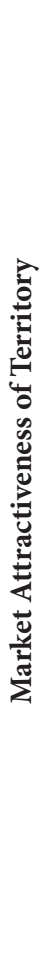 } & & Strong & Medium & Weak \\
\hline & 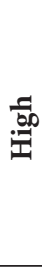 & $\begin{array}{l}\text { Protect Position } \\
\text { - Invest to grow at maximum } \\
\text { digestible rate (average for all } \\
\text { companies of territory) } \\
\text { - Concentrate efforts on } \\
\text { maintaining strength of com- } \\
\text { panies of territory }\end{array}$ & $\begin{array}{l}\text { Invest to build } \\
\text { - Challenge for leadership } \\
\text { - Build selectively on } \\
\text { strengths } \\
\text { - Reinforce vulnerable areas }\end{array}$ & $\begin{array}{l}\text { Build Selectively } \\
\text { - Specialize around limited } \\
\text { strength } \\
\text { - Seek ways to overcome } \\
\text { weaknesses } \\
\text { - Withdraw if indications of } \\
\text { sustainable growth are lucking }\end{array}$ \\
\hline & 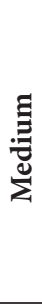 & $\begin{array}{l}\text { Build Selectively } \\
\text { - Invest heavily in most } \\
\text { attractive segments of the ter- } \\
\text { ritory business } \\
\text { - Build up mobility for coun- } \\
\text { ter competition } \\
\text { - Emphasize profitability by } \\
\text { raising productivity }\end{array}$ & $\begin{array}{l}\text { Selectivity / Manage for } \\
\text { Earnings } \\
\text { - Protect existing programs } \\
\text { - To help for concentration } \\
\text { of investments in segments } \\
\text { when profitability is good } \\
\text { and risks are relatively low }\end{array}$ & $\begin{array}{l}\text { Limited Expansion or Harvest } \\
\text { - To help companies of terri- } \\
\text { tory to look for ways to expand } \\
\text { without high risk; } \\
\text { - Otherwise to help for mini- } \\
\text { mization of investments and } \\
\text { rationalize the operations }\end{array}$ \\
\hline & ) & $\begin{array}{l}\text { Protect and Refocus } \\
\text { - To provide the companies } \\
\text { of information to manage for } \\
\text { current earnings } \\
\text { - To help to concentrate on } \\
\text { attractive segments } \\
\text { - Defend strengths by local } \\
\text { legislation }\end{array}$ & $\begin{array}{l}\text { Manage for Earnings } \\
\text { - Protect positions in most } \\
\text { profitable segments } \\
\text { - To help companies to up- } \\
\text { grade product lines, and to } \\
\text { minimize investments in not } \\
\text { attractive in territory lines }\end{array}$ & $\begin{array}{l}\text { Divest } \\
\text { - To inform companies for the } \\
\text { purpose to help them to sell } \\
\text { the product at time that will } \\
\text { optimize profit } \\
\text { - To consult the companies } \\
\text { about strategy to cut fixed } \\
\text { costs and to avoid meaningless } \\
\text { investments in the region }\end{array}$ \\
\hline
\end{tabular}


To specify the elements of business/organizations competitiveness on territories, it is possible to point on 10 parameters (indicators):

- Are there enough of qualified personnel in organizations?

- Are organizations well adapted for changes? Are they ready to implement the innovations?

- Are organizations well equipped with material resources?

- Are the distribution systems for produced goods well developed?

- Does the business activity in the territory have a good capacity?

- Do sustainable advantages for business exist in the territory?

- Does a high reputation for produced goods and business activity exist in the territory?

- Is the business in the territory effective in an economic sense?

- Does infrastructure support for business activity (including regulation acts, communications, information network) in the territory exist?

- Does the business have sustainable contacts with different actors in the territory?

To specify the level of some business attractiveness for a territory (second dimension of Matrix), it is possible to name also 10 parameters, namely:

- Pressure on the territorial infrastructure

- Dependence on external (imported) components and raw materials

- Influence on the territory's budget of and taxation base

- Establishing of local networks and the production of product chains

- The life cycle of produced products (inside or outside of territory)

- Influence on social sphere

- Influence of local labour market

- Necessity of lobbying

- Peculiarities of local competition

- Possibility to explore the territorial resources and other positive aspects of local life.

The dimensions of the Matrix can be established in grades, for example, $100 \mathrm{X}$ 100. Each indicator can be a variable from 1 to 10 (expert evaluation), and the total score can be measured for every specific territorial business situation. The lowest scores demonstrate the "narrow places" for business development in the territory, and if some "narrow places" in the Matrix are the same, it shows the strategic weakness for business development in the territory in given indicators. If a certain group of companies in the territory is located in the left upper corner of the Matrix (Table 3), and if the group is demonstrating its technological and infrastructural relations, it clearly can be named as the core for the potential cluster development of the territory. And, vice versa, the "narrow places", or weak elements of the Matrix, that are possible to regulate, can be used as the foundation for improvement of the cluster structure of a territory.

The positive moments of the new Matrix as an analytic tool for territorial development strategy are numerous. First of all, it is based on measured indicators. Secondly, it takes into account the views on systemic territorial development risks. Thirdly, this Matrix is clearly connected with a McKinsey-type Matrix which is a well-recommended instrument for the evaluation of business organization stra- 
tegic development. Finally, it is an alternative approach toward the evaluation of territory development which is based on ex-ante models of evaluation. It is, in some ways, much more attractive than ex-post evaluation.

Table 3

\section{Potential for cluster development in the territory (example)}

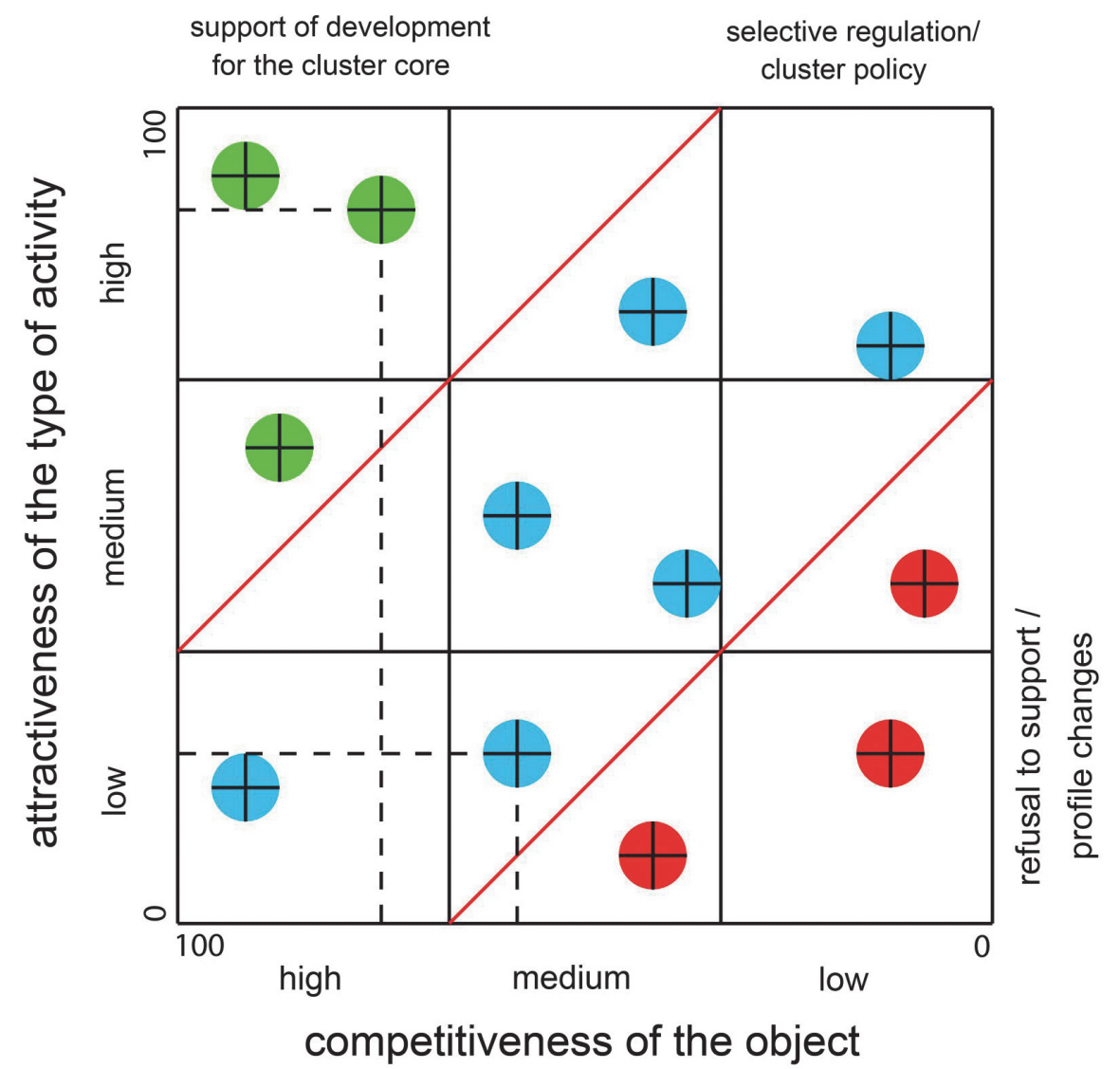

Implementation: Evaluation of a selected Russian region's strategy based on a McKinsey-type matrix

Selected Region: Kamchatka. To show how it is possible to evaluate the strategy of territorial development by a McKinsey-type matrix, it is reasonable to select regions with clear problems and a high potential for business development progress. For Russia, it is reasonable to select, as an example, the region that is located far from central parts of the country because the risks to development here are much higher, and the potential for business should be evaluated more accurately with the use of new analytic tools.

An additional argument for selecting Kamchatka as the "test" for McKinseytype matrix usage is that the Far East of Russia was announced as one of the top priorities for strategies of regional development elaboration. Moreover, a specia- 
lized Ministry for priority program elaboration and implementation in the region was established namely, the Federal Russian Ministry for Far East Development ${ }^{7}$.

Kamchatka Oblast (a region in the Far East of Russia) appears to completely satisfy the criteria of selection: underdevelopment, high risk for investment due to its distance from central regions of Russia, and great potential for future economic growth. First of all, it is a depressed region that has received a lot of resources from the Federal Government. To evaluate how better to invest money to encourage potential investors to Kamchatka is the sine qua non for the effective spending of federal resources. Second, Kamchatka region is not just located far from Central Russia: it is a peninsula with a problematic transportation system, low quality roads (mostly seasonal use) and a small population on a large territory with extreme climate conditions. Mobility of human resources and the capacity for transportation of mineral resources and goods is quite limited. Seismic and volcanic activity prevents safe exploration in some areas. At the same time, it is a biggest non-frozen port in the Russian Far East with a direct gateway to Pacific Ocean routes and it has the biggest access to marine bio-resources. Last but not least, the largest military base of the Russian Fleet is located in the area, and it is a paramount requirement for the geo-political and economic support of the region, which are difficult to provide through federal budget sources alone.

Additional arguments to choose Kamchatka are provided by the possibility to compare the proposals for the Kamchatka strategy (as per the results of our research) with the proposals produced by the Strategy of social-economic development of Kamchatka which was issued in 2010 and will expire in $2025^{8}$.

From a theoretic standpoint, the reasons for selecting Kamchatka region for analysis by the tool of a McKinsey-type matrix are connected with the logically simple definition of the elements of the matrix. Namely, the elements for analysis (possible activity areas for business; list of clusters; competition indexes) are clearly defined and limited in number.

Functional analysis is much easier for the chosen region. The functions of regional bodies and of the regional government as a whole in Kamchatka are limited and can be evaluated by experts more similarly (without controversy) than for the regions of Russia with heterogeneous and complicated conditions and distributed economic potential (as with Moscow, Volga, and Central Siberia regions).

To sum up, theoretically the selection of Kamchatka region as the pattern for McKinsey-type matrix construction and for the evaluation of the strategy for regional development seems appropriate because Kamchatka region satisfies the criteria of both institutional approach (function analysis) and of geographical zone specification (clusters).

McKinsey-type matrix for Kamchatka. The key point for McKinsey-type matrix shaping is to evaluate the risks to different kinds of business activity based on expert evaluations. Experts should know the situation in the region in detail, and

\footnotetext{
Postanovleniye Pravitelstva Rossyskoy Federatsii ot 30 iyunya 2012 g. № 664 O Ministerstve Rossyskoy Federatsii po razvitiyu Dalnego Vostoka. http://minvostokrazvitia.ru/images/downloaded/pprf664.pdf

8 Strategiya sotsialno-ekonomicheskogo razvitiya Kamchatskogo kraya do 2025 goda ot 27.07.2010. http:// www.kamchatka.gov.ru/oiv_doc/22/8862.rar
} 
clarify risks and opportunities according to the matrix components. For Kamchat$\mathrm{ka}$, the unique possibility to work with experts was created due to the special educational program (executive MPA program) that was organized through the Russian Academy of National Economics and Public Administration (RANEPA) under the President of Russia in 2014/2015. Among the participants of the expert group, representatives of the following were present: the Administration of Kamchatka and neighbouring regions' administrations, municipal authorities, local business (services, manufacturing, mineral resources, etc.), public organizations of the region, and Federal authorities involved in decision-making for Kamchatka region..

The group was involved in in-depth discussions about existing strategic documents on development in Kamchatka region, both general strategy documents and branch strategies for different areas of economics (examples of the sector strategies are shown in the notes ${ }^{9}$ ). Statistic data for strategy evaluation concerning Kamchatka region was provided by sources, mostly those published by Federal and regional statistics organizations ${ }^{10}$. This included data about conditions in the social, infrastructural, and economic life of Kamchatka region.

At the next stage, the experts were asked to evaluate (10-score scale for every position) different kinds of activity, the attractiveness of each for business, including risks, and the ability of the region to compete in given selected areas according to the columns and rows of the McKinsey-type matrix (in general, 10 positions of attractiveness, and 10 positions of competitiveness). The experts' scores were averaged for every indicator, and the averaged indicators of the 10 positions mentioned (attractiveness/competitiveness) were summed up. Finally, for each kind of activity in Kamchatka region we have found two averaged expert evaluative scores (from 1 to 100) that determine an activity area position in the matrix at the coordinates of "competitiveness" and "attractiveness" respectively.

The essence of a matrix evaluation, as argued earlier, is to elaborate the best decisions for a strategy shaping regional development. It is a guide for strategy shaping and investment optimization. In other words, to invest the federal and regional sources into areas selected by experts could be more fruitful for the pros-

\footnotetext{
9 Strategiya sotsialno-ekonomicheskogo razvitiya Kamchatskogo kraya do 2025 goda (Morekhozyaystvenny blok) ot 21.07.2010. http://www.kamchatka.gov.ru/oiv_doc/22/8135.rar Strategiya razvitiya energetiki Kamchatskogo kraya na period do 2025 goda ot 17.11.2010 № 561-RP. http://www.kamchatka.gov.ru/ oiv_doc/2589/9624.rar;

Strategiya razvitiya sudoremontnoy otrasli Kamchatskogo kraya do 2025 goda. http://www.kamchatka.gov. ru/oiv_doc/2681/8863.doc;

Strategiya razvitiya dobychi i pererabotki mineralno-syryevykh resursov v Kamchatskom kraye na period do 2025 goda. http://www.kamchatka.gov.ru/upfiles/167/strategy.rar;

Strategiya razvitiya rybopromyshlennogo kompleksa Kamchatskogo kraya do 2025 goda ot 16.02.2011 http://www.kamchatka.gov.ru/oiv_doc/3006/16355.doc;

Strategiya razvitiya turizma v Kamchatskom kraye do 2025 goda ot 24.12.2010. http://www.kamchatka.gov. ru/oiv_doc/452/10030.rar

10 Makroekonomicheskiye pokazateli po Kamchatskomu krayu za 2014 god ot 26.01.2015. http://www. kamchatka.gov.ru/oiv_doc/19/35733.doc;

Makroekonomicheskiye pokazateli po Kamchatskomu krayu za 2009 god ot 25.01.2010. http://www.kamchatka. gov.ru/oiv_doc/19/5360.doc;

Regiony Rossii. Osnovnye kharakteristiki subyektov Rossyskoy Federatsii. (2014): Stat. sb. / Rosstat. - M. - 652 s.; Regiony Rossii. Sotsialno-ekonomicheskiye pokazateli. (2014): Stat. sb. / Rosstat. - M. - 900 s.
} 
pects of private investors, from the perspective of private -state entrepreneurship elaboration. Table 4 shows the configuration of positions in a McKinsey-type matrix for Kamchatka region.

Table 4

\section{McKinsey-type matrix of regional development} for Kamchatka region

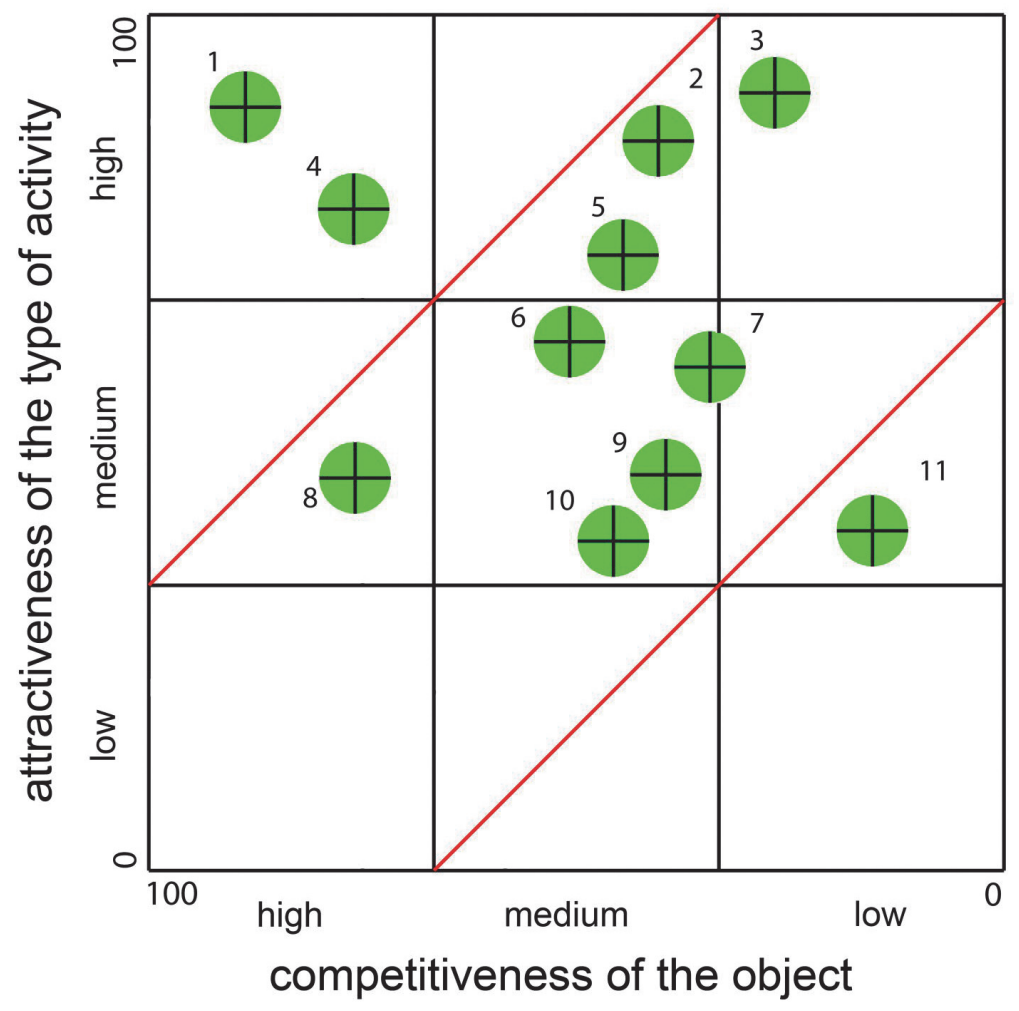

1 - industry of fishing and of fish products

2 - tourism

3 - sea transportation

4 - construction of ships, and ship repair (shipyards, dockyards)

5 - energy production

6 - mineral resources production

7 - agriculture and aquaculture

8 - trade

9 - air transportation

10 - forest/wood industry

11 - manufacturing

To analyze the matrix, some non-trivial results, as in proposals for strategy development in Kamchatka region, can be discovered. One of two priority areas of activity here are the so-called "marine cluster", including fishing and ship con- 
struction. This was more attractive to the experts than tourism, trade, energy and mineral resources production. This is because activity area factor-analysis shows it to be the best combination of competitiveness and attractiveness indexes. It is a non-trivial result because the "peak" of attractiveness belongs to tourism, and the "peak" of competitiveness is reserved for trade. But, tourism and trade are not balanced positions, and this means that to give support and to set strategic stakes on tourism and on trade in Kamchatka can be too risky. Additionally, the in-depth analysis of other positions in the McKinsey-type matrix for Kamchatka could help to eliminate bottle necks in the development of other areas presented by the matrix (see list of areas of activity above).

One of the key principles of our analysis is: a selected group of experts has the "natural rights" to shape the strategy for Kamchatka region, despite its limited size. It is not correct to say that the group is too small, not representative, or too opinionated. They are stakeholders, and their collective position should be taken into account. Of course, it is possible to compare the preferences of stakeholders with the preferences (also in McKinsey matrix form) of a group of academic experts, of representatives of civil society groups, and of small and medium entrepreneurships (SME), which should be much bigger in size and rich in selection criteria. However, stakeholders' preferences have an independent value.

Additionally, it is possibly to compare two McKinsey matrixes: the current one and the previous one that represents the preferences of stakeholders five years ago. The difference in preferences could reveal the trends and identify the reasons for changes in trends. And last but not least: it is possible to use the results of research for recommendations to reshape the cluster policy for the Far East region as a whole.

\section{Conclusion}

The methodology of McKinsey-type strategic matrix preparation, demonstrated in the Kamchatka case, can be transferred to other regions with much more complicated conditions and divergence in the activity areas. It should be accepted as the universal tool for strategies of territorial development elaboration. However, to move ahead one should add some additional elements to the methodology described above. Among these, three requirements could be noted. First, it is useful to construct the McKinsey-type matrix for a region not on the basis of one year of statistic data and one single expert group evaluation, but to repeat such a procedure at least twice (two years), just to avoid mistakes in the collective expert positions and to eliminate any fluctuations in statistics. Second, it is a fruitful task to compare the McKinsey-type matrix for neighbouring regions, and for regions participating in inter-regional cooperation. It could coordinate their strategies and achieve the effect of multiplication. Third, theoretically the middle ground for theories of clusters and theories of institutional analysis should be fulfilled by theories of regional strategy construction and evaluation. A strategic approach toward regional development should be grounded on the basis of ex-ante evaluation instruments, and a McKinsey-type matrix approach can be utilized for such a theory. 


\section{REFERENCES}

1. Aaker, D.A. (1995). Strategic Management. 4th ed., New York, NY: John Wiley \& Sons Ltd.

2. Andersson, T., Hansson, E., Serger, S.S. \& Sörvik, J. (2004). The Cluster Policies Whitebook. Malmö: IKED.

3. Barabashev, A. \& Semenov, S. (2014). How to Improve the Evaluation on Municipal Management Effectiveness: The Moscow and Moscow Region Experience. The NISPAcee Journal of Public Administration and Policy, Special Issue: Strong Local Governments: Community, Strategy, Integration, vol. VII, n. 2, Winter 2014/2015, Bratislava, NISPAcee Press, pp. 35-50.

4. Diversification of Kazakhstan's Economy Through Cluster Development In Non-Extracting Economic Sectors. In Report on Phase One Analytics and Summary of Other Component Activity. Government of Kazakhstan. Center for Marketing and Analytical Research. Almaty, Kazakhstan, August 2004.

5. Enduring Ideas: The GE-McKinsey Nine-Box Matrix (2008) September. Available: http://www.mckinsey.com/insights/strategy/enduring_ideas_the_ge_and_mckinsey_ nine-box_matrix (accessed: 10 December, 2015).

6. Enright, M.J. (2000). The globalization of Competition and the Localization of Competitive Advantage: Policies towards Regional Clustering. In: N. Hood and S. Young (eds.), Globalization of Multinational Enterprise Activity and Economic Development. MacMillan, London, pp. 303-332.

7. Glasmeier, A.K. (2000). Economic Geography in Practice: Local Economic Development Policy. In: G.1. Clark, M.P. Feldman and M.S. Gertler (eds.). The Oxford Handbook of Economic Geography. Oxford: Oxford University Press.

8. Hax, A.C., \& Majluf, N.S. (1990). The use of Industry Attractiveness-Business Strength Matrix in Strategic Planning. In: R.G. Dyson (ed.). Strategic Planning: Models and Analytical Technique. Chischester, England: John Wiley \& Sons, pp. 73-92.

9. Johnson, G., Scholes K. \& Whittington R. (2007). Korporativnaya strategiya: teoriya $i$ praktika [Corporate Strategy: Theory and Practice]. 7th Issue. Translated from English. Moscow: Vilyams.

10. McKinsey Matrix GE Business Screen. Available: http://www.12manage.com/methods_ ge_mckinsey.html (accessed: 10 December, 2015).

11. Mulgan, G. (2011). Iskusstvo gosudarstvennoy strategii: Mobilizatsiya vlasti i znaniya vo imya vseobshchego blaga [The Art of Public Strategy: Mobilizing Power and Knowledge for the Common Good]. Translated from English. Moscow: Institut Gaydara.

12. Nikolaev, I.A. \& Tochilkina, O.S. (2006). Analiticheskiy doklad. Strategii I programmy razvitiya regionov (Sravnitelnyi analiz) [Analytical Report. Strategies and Programs of Regional Development (Benchmarking)]. Moscow: FBK. Available: http://www. adm.yar.ru/dms/recommendation/regions.pdf (accessed: 10 December, 2015). 
13. OECD (2001). Issues paper. World Congress on Local Clusters: Local Networks of Enterprises in the World Economy. Paris, 23-24 January.

14. Porter, M.E. (2005). Konkurentsiya. Translated from English. Moscow: Vilyams.

15. Regional clusters in Europe. European Communities. Observatory of European SMEs. 2002, n. 3, p. 9.

16. Roelandt, T.J.A. \& den Hertog, P. (1999). Cluster Analysis and Cluster-Based Policy Making in OECD Countries: Introduction to the Theme. In: T. Roelandt and P. den Hertog (eds.) Cluster Analysis and Cluster-based Policy: New Perspectives and Rationale in Innovation Policy. Paris: Organization for Economic Cooperation and Development, April.

17. Sölvell, Ö., Lindqvist, G. \& Ketels, Ch. (2003). The Cluster Initiative Greenbook. Gothenburg: The Competitiveness Institute/VINNOVA.

18. Strategiya sotsialno-ekonomicheskogo razvitiya Vologodskoy oblasti, 2013 [Strategy of Social and Economic Development of the Vologda Region, 2013]. Available: http://www.invest35.ru/assets/files/docs/se/Soc-ec_strategy.pdf (accessed: 10 December, 2015). 